\title{
Variability of water storage capacity in three lichen species
}

\section{Anna Klamerus-Iwan ${ }^{1}$ (D) Rafał Kozłowski $^{2}$ (D) Joanna Przybylska $^{2}$ (D) $\cdot$ Wiktor Solarz ${ }^{1} \cdot$ Wojciech Sikora $^{1}$}

Received: 12 August 2019 / Accepted: 23 January 2020 / Published online: 11 February 2020

(C) The Author(s) 2020

\begin{abstract}
As poikilohydric organisms, lichens are capable of storing significant amounts of atmospheric water. Epiphytes that intercept rainfall change the amount and chemical composition of throughfall water, affecting water balance and microclimate of forest ecosystems. The aim of the study was to investigate the differences in the process of changes/increase in the amount of water in three lichen species: Evernia prunastrii, Hypogymnia tubulosa and Platismatia glauca. In the experiment, conducted under laboratory conditions, samples of thalli were wetted with constant doses of water and weighed in order to determine the amount of water storage capacity from simulated rainfall. The studied lichen species differed in terms of process dynamics and values of water storage capacity, probably due to the morphological structure of thalli. Average water retention was the highest in Platismatia glauca (33.58 \%), lower in Evernia prunastrii (19.77\%) and the lowest in Hypogymnia tubulosa (15.38 \%). Analyzed taxa with larger water storage capacity are also known to be more sensitive to air pollution.
\end{abstract}

Keywords Ecohydrology $\cdot$ Epiphyte $\cdot$ Forest retention $\cdot$ Pollution $\cdot$ Rainfall $\cdot$ Water storage capacity

\section{Introduction}

As poikilohydric organisms with distinct morphological and physiological features, lichens, i.e. lichenised fungi, are able to absorb atmospheric water from the thallus surface. Apart from the growth form, determining surface area to volume ratio, some taxa have structures facilitating gas exchange, i.e. cyphellae and pseudocyphellae, enabling a higher water uptake and accumulation of contaminants (Jóźwiak 2014). Lichens are capable of storing even $3360 \%$ of their dry weight in water; however, thallus supersaturation depresses photosynthesis (Lichner et al. 2012); and species from moist microhabitats have developed mechanisms to avoid excessive water

Anna Klamerus-Iwan

a.klamerus-iwan@ur.krakow.pl

Rafał Kozłowski

rafal.kozlowski@ujk.edu.pl

Joanna Przybylska

joanna.przybylska@tbop.org.pl

1 Faculty of Forestry, Department of Forest Engineering, University of Agriculture in Krakow, Al. 29 Listopada 46, 31-425 Krakow, Poland

2 Institute of Geography and Environmental Sciences, Jan Kochanowski University, ul. Uniwersytecka 7, 25-406 Kielce, Poland uptake (Hauck et al. 2008). Lichens can also absorb water from fog (Maphangwa et al. 2012). Due to their functional variability, lichens are present in nearly all climate regions. They dominate ca. $10 \%$ of terrestrial ecosystems, covering areas with extreme conditions, inaccessible to most vascular plants, i.e. deserts, tundra and alpine habitats (Honegger 2007). Pypker et al. (2006) specifically mentions arboreal epiphytic lichens and their role in the canopy.

As lichens intercept and gradually evaporate rainwater, their presence modifies microclimate (Porada et al. 2014; Van Stan and Pypker 2015). Epiphytes significantly change the amount of water reaching the soil (Prada et al. 2009, 2012; Figueira et al. 2013) and reduce soil erosion (Lichner et al. 2012; ك̌urda et al. 2015; Yousefi et al. 2018). The global abundance of lichens, their high absorbency and efficient interception of atmospheric water suggest that they could play an important role in the forest water budget (Porada et al. 2018). Moreover, the accumulating capacity of epiphytic lichens can significantly decrease the concentration of trace elements in throughfall water (Cercasov et al. 2002). Phinney (2019) uses 3D modelling of topography of Lobaria pulmonaria thallus to facilitate the understanding of water storage pools.

Lichens also have the function of indicator species (bioindicators) (Hawksworth and Rose 1970). The lichen scale has been developed by Kiszka (1990) and modernised by Bielczyk (2001). On the lichen scale, 7 zones were 
identified depending on the $\mathrm{SO}_{2}$ concentration $\left[\mu \mathrm{g} / \mathrm{m}^{3}\right]$. Zone I: above $170 \mu \mathrm{g} / \mathrm{m}^{3}$, is the so-called lichen desert; zone II ranges from 100 to $170 \mu \mathrm{g} / \mathrm{m}^{3}$; zone III has $70-100 \mu \mathrm{g} / \mathrm{m}^{3}$; zone IV: $50-70 \mu \mathrm{g} / \mathrm{m}^{3}$; zone V: $40-50 \mu \mathrm{g} / \mathrm{m}^{3}$; zone VI has $30-40 \mu \mathrm{g} / \mathrm{m}^{3}$; and zone VII is below $30 \mu \mathrm{g} / \mathrm{m}^{3}$. The higher the zone, the lower the contamination tolerance range. The lichen structure is also associated with tolerance to pollution. In zone II, lichens usually have a crusty thallus. In zone III lichens are fine-leaved whereas in zone IV they are leafy, and this is where Hypogymnia psysodes belongs. In zone V, next to leafy lichens, bushy species such as Evernia prunastri appear. Zones VI and VII include all previous lichens types as well as one of the more demanding species in terms of air purity: Platismatia glauca. Poleotolerance as well as structure types has also been included in the Italian classification:

(http://dryades.units.it/italic/?procedure $=$ base $\& \mathrm{t}=59 \& \mathrm{c}=$ 60\#growth:\%20growth $\% 20$ forms $\% 20$ of $\% 20$ lichens).

Total rainfall interception by forests includes both water storage and evaporation processes. The dynamic interchange between this state (storage) and flux (evaporation) can be a complex, because it depends on the spatial heterogeneity of canopy surfaces, their surface characteristics, and rainfall conditions (Dohnal et al. 2014). A key trait for integration of canopy elements into rainfall interception models is the water storage capacity under given conditions (often determined under simulated rainfall conditions). Thus, the aim of the study was to investigate the differences in the total water storage capacity and temporal variability for three lichen species common to Northeastern Poland, under simulated rainfall conditions. Moreover, the results obtained were compared with the resilience of various lichens to air pollution.

\section{Material and methods}

\section{Analysed species of lichens}

The samples were collected in the Puszcza Borecka Forest (NE Poland). The area of ca. 18 thousand hectares is dominated by deciduous and mixed forests with a significant share of spruce, some parts are also covered by coniferous mixed-species stands, bog woodlands and alluvial forests (Kondracki 1972). It is one of the areas of the best air quality in Poland (GIOŚ 2018).

In terms of climate regionalisation, the research area is located in the Wegorzewo Region, where the mean annual temperature is $6.1-6.5^{\circ} \mathrm{C}$, the coldest month is February (the mean ca. $4{ }^{\circ} \mathrm{C}$ ), the warmest month is July (the mean ca. $+16.8^{\circ} \mathrm{C}$ ) and the growing season lasts ca. 200 days (Stopa-Boryczka 1986). Rainfall frequency in the Wegorzewo Region (170 - 180 days of $>0.1 \mathrm{~mm}$ precipitation) is higher than in many parts of Polish lowlands (Woś 1999). Its annual precipitation has been given as ranging from 620 to $660 \mathrm{~mm}$ (Stopa-Boryczka 1986) and up to $700 \mathrm{~mm}$ (Woś 1999), as in the other postglacial lakelands of northern Poland with elevations of $200 \mathrm{~m}$ a. s. 1. or more, which trap humid polar maritime air masses moving from the northwest. More recent measurements from the Puszcza Borecka Forest show annual precipitation ranging from 494.5 to $855.7 \mathrm{~mm}$ in 2003 and 2007 (Skotak et al. 2018). The climate of the examined area and especially of the Puszcza Borecka Forest is influenced by the landforms and landscape (related to the presence of high morainal hills; as mentioned above) as well as the microclimate resulting from the local relief and plant cover types (Zalewska 2012). All major young glacial landforms can be found here, with clear domination of hilly ground moraine areas showing highly diversified relief, with elevations of $133-223 \mathrm{~m}$ a.s.l. and many hills above $200 \mathrm{~m}$ a.s.l. Local height differences are considerable (on average $20-50 \mathrm{~m}$, max. $90 \mathrm{~m}$ ). The largest area is covered by subcontinental Tilio-Carpinetum forest showing considerable local habitat variation related primarily to soil moisture and nutrient content (Polakowski 1961; Polakowski 1963; Endler et al. 1991; Matuszkiewicz 2005). Tilio-Carpinetum typicum phytocoenoses are most common, occurring on slopes and flat-topped hills. Multilayered stands are typically composed of hornbeam Carpinus betulus, common oak Quercus robur, small-leaved linden (lime) Tilia cordata, and Norway spruce Picea abies as a naturally accompanying species (Czarnota and Kukwa 2008).

Lichen samples were collected in the area of Podleśne village in the Puszcza Borecka Forest on 31.03.2019. Based on meteorological data obtained from the Mikołajki station approx. $40 \mathrm{~km}$ from the sampling site, it was noted that the average daily temperature amounted to $6.9^{\circ} \mathrm{C}$, while the monthly average was $4.4{ }^{\circ} \mathrm{C}$; and the relative air humidity was $66 \%$, while the monthly average was $75 \%$ (https://en. tutiempo.net/climate/2019/ws-122800.html). On that day, no precipitation was recorded and the monthly precipitation average amounted to $38.9 \mathrm{~mm}$. In the period preceding the sampling (from 20th March), the average daily temperature ranged from 1.2 to $10.6{ }^{\circ} \mathrm{C}$, whereas the average daily humidity ranged from 61 to $85 \%$. In that period, the total precipitation amounted to $5.9 \mathrm{~mm}$ as recorded on 27th and 28th March, i.e. 3 and 4 days before the sampling.

Tree lichen species were analysed in the experiment. Hypogymnia tubulosa (Fig. 1) has a foliose, rosette-like thallus with tubular lobes adhering to the substrate. Soredia are grouped into convex knots, located at the end of lobes. Platismatia glauca (Fig. 2) forms large, foliose thalli with broad, upcurved lobes, corrugated margins and marginal isidia and soredia. Evernia prunastri (Fig. 3) has a fruticose or subfruticose, branched thallus, drooping or erect, with flat, pitted and rugose lobes. Soredia are numerous, often on ridges and margins (Faltynowicz 2012). Lichen samples located on dry branches were collected at the height of $1-3 \mathrm{~m}$ above ground from living spruce tree stems. 


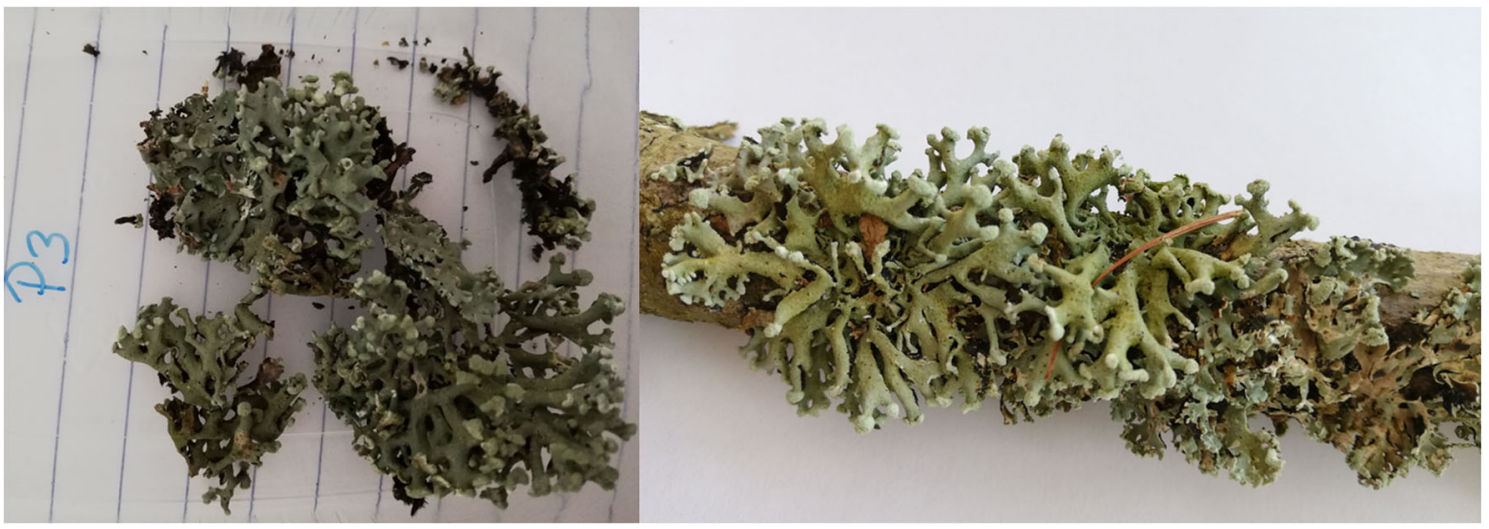

Fig. 1 Hypogymnia tubulosa

As in other areas dominated by forest communities, the lichen biota of the analysed area consists mainly of epiphytes (Cieśliński and Tobolewski 1988; Cieśliński 1995, 1997; Cieśliński et al. 1995; Bystrek and Kolanko 2000). Sixtyeight percent of all identified species were found on the bark of trees, $38 \%$ on dead wood, $35 \%$ on rocky substrates and $11 \%$ on the ground (Zalewska 2012). The main morphological forms of the recorded lichens show a percentage structure typical of woodland, with predominance of species having crustose thalli $(71 \%)$ and low shares of foliose $(16 \%)$ and fruticose $(13 \%)$ lichens. These relations are shaped by the abundance of epiphytic lichens, which have an almost identical percentage structure of forms. The percentages of foliose and/or fruticose forms are higher in the other habitat groups, probably due to the higher frequency of their substrates in well-insolated places.

Among the ecological groups, the epiphytes had the most diverse taxonomic composition (206 species) and the largest share of species with a high number of records (Zalewska 2012).

\section{Measurements of water storage capacity}

The samples were transported on spruce branches. For each species, 15 fragments of thallus of different sizes were selected. The experiment was conducted under laboratory conditions (temperature $21{ }^{\circ} \mathrm{C}$, air humidity $52 \%$ ). All samples were stored under the same conditions and wetting was performed on a single day so as to ensure result comparability. The measurements were divided into 21 runs, during which the samples were wetted with constant doses of water $(P=$ $10 \mathrm{~g}$ ). Each run lasted for $15 \mathrm{~s}$ and a subsequent dose of water was sprayed immediately after the sample was weighed. The average intensity of simulated rainfall amounted to $0.68 \mathrm{~g} \cdot \mathrm{s}^{-1}$. The wetting was performed using a garden sprinkler. The sprinkler nozzle was supported on a stand, on a constant level above the lichen sample. Water doses were measured from a calibrated container. Lichen samples were arranged on a mesh base above the container (Fig. 4). The lichen thallus was separated by means of tweezers from the tree bark on which it had been transported. The purpose was to eliminate water interception by the bark. The difference in the weight of a sample before and after wetting was equal to the amount of water (W) stored by lichen thalli in each run. The results of subsequent measurements reflected the increase in the weight of water intercepted by the lichens. The actual water storage capacity (S), i.e. water gain after each rainfall dose, was calculated per unit of wet biomass (bm). Relating water storage capacity to biomass and the relevant calculations are based on other studies (Garcia-Estringana et al. 2010). Water storage capacity in

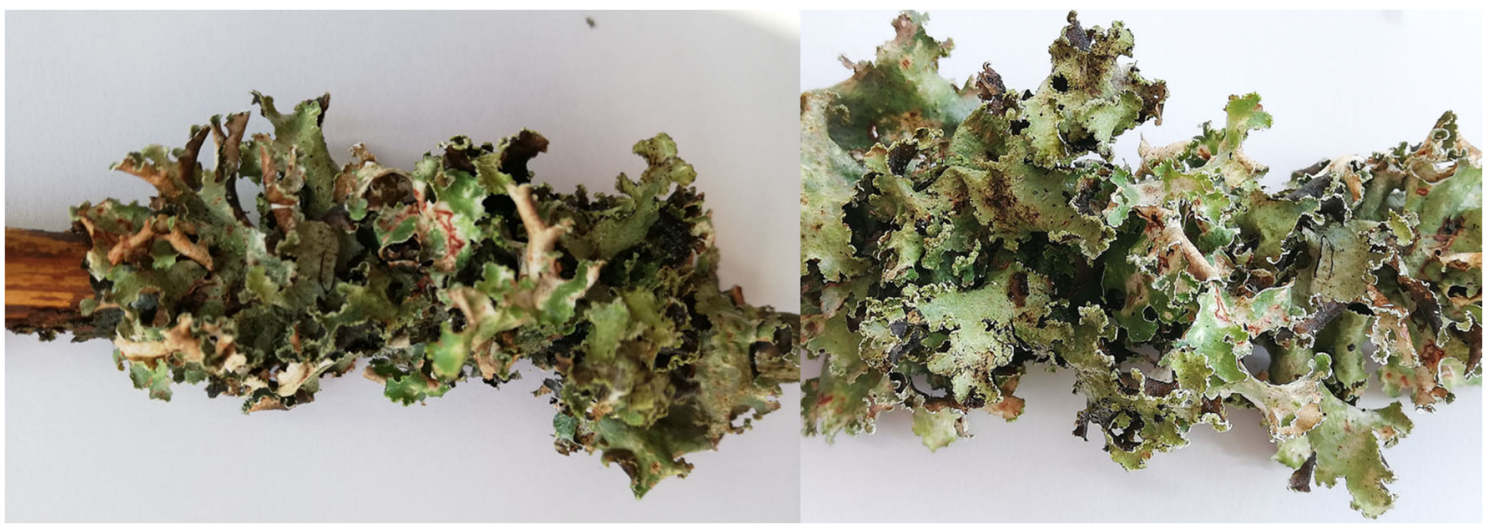

Fig. 2 Platismatia glauca 


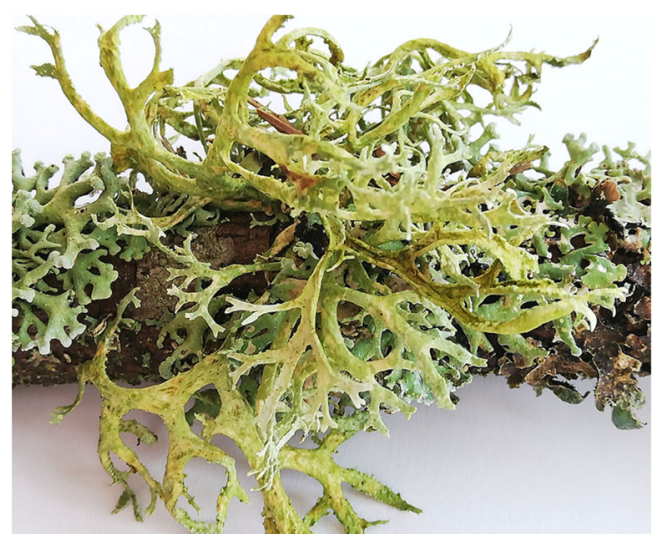

Fig. 3 Evernia prunastri

grams of water per gram of thalli $\left[\mathrm{g} \cdot \mathrm{g}^{-1}\right]$ was converted to the percentage gain of stored water, where each dose was treated as $100 \%$ of rainfall. Water storage capacity expressed as a proportion of rainfall provides a better understanding of the amount of water absorbed by lichens. Water storage capacity is presented as a process of filling a container, which, in this experiment, was the sample of lichen thalli.

\section{Statistical analysis}

One-way analysis of variance was performed in order to verify the differences between the taxa. Multiple comparisons were conducted with the Sidak post-hoc test, using an index derived from the mean results of 21 water storage capacity measurements.

A series of regression analyses was conducted to find the model describing the relationship between time (subsequent doses of water) and value of water retained on a lichen sample. Linear, logarithmic, inverse, quadratic and cubic functions were tested. The coefficient of determination $\left(R^{2}\right)$ was used to evaluate the goodness-of-fit of the models. A higher value of $R^{2}$ indicates a higher proportion of total variation of the

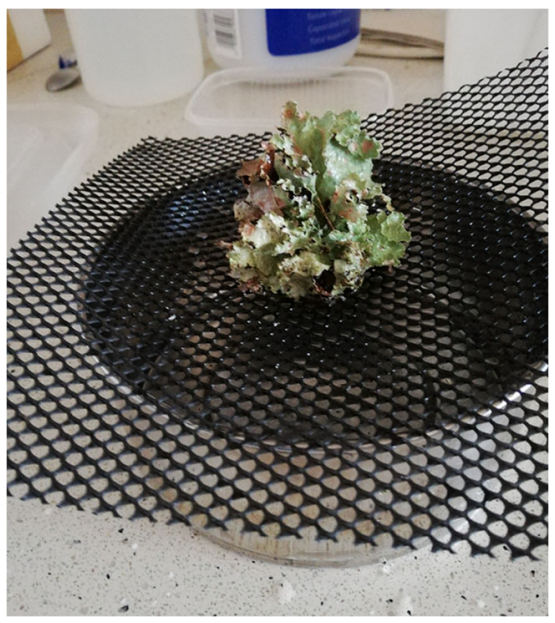

Fig. 4 Lichen thallus sample on a mesh before simulated rainfall observed phenomenon explained by the model. In the last step, a cubic function was adapted and regression analysis was performed for each lichen species separately.

\section{Results}

\section{Differences in the water storage capacity of lichen species}

There was a statistically significant difference between the taxa in terms of the mean value of water storage capacity, as determined by one-way ANOVA $(F(2.942)=930.49$, $\left.p<0.001, \eta^{2}=0.66\right)$. The Sidak post-hoc test revealed that the water storage capacity value was the highest in Platismatia glauca, lower in Everenia prunastri and the lowest in Hypogymnia tubulosa: $33.58 \%$ vs. $19.77 \%$ vs. $15.38 \%$, respectively (Fig. 5).

\section{Relationship between time and water storage capacity}

The process of water storage capacity in 21 runs of the experiment was best described by a cubic function. With the first doses of water water storage capacity was growing dynamically, then it decreased and slightly increased again in the last measurements. The test results for each model are presented in Table 1. Parameters of the cubic function relating time (subsequent doses of water) and value of water storage capacity are presented in Table 2 and the curve is given in Fig. 6.

\section{The cubic model for the water storage capacity of three lichen species}

A regression analysis indicated that in all samples of lichen taxa each subsequent dose of simulated rainfall significantly affected the value of water storage capacity; Everenia prunastri $\mathrm{F}(3.311)=78.33, p<0.001 ;$ Hypogymnia tubulosa

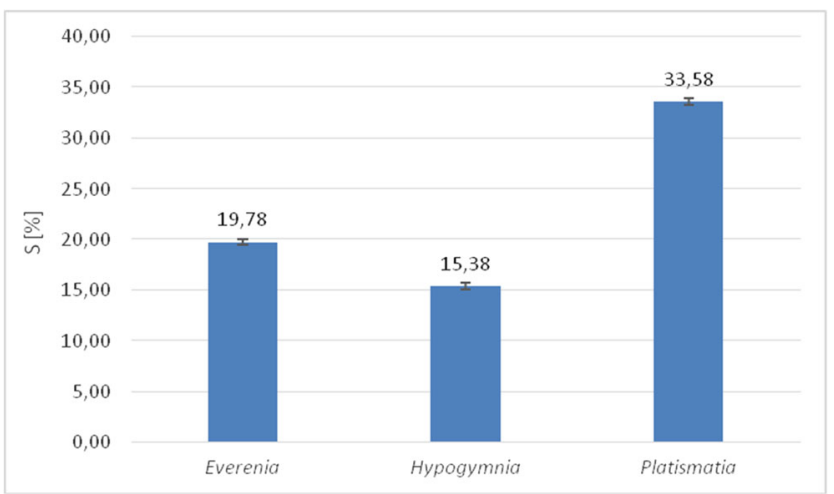

Fig. 5 Differences in water storage capacity of three lichen species. Error bars indicate the standard error of the mean. S [\%] - water storage capacity as the portion of simulated rainfall stored by lichens 
Table 1 Test results for analysed models

\begin{tabular}{lllll}
\hline Function & $R$ & $R^{2}$ & $R^{2}{ }_{\text {adj }}$ & $S E$ \\
\hline Linear & 0.35 & 0.12 & 0.12 & 8.91 \\
Logarythmic & 0.40 & 0.16 & 0.16 & 8.73 \\
Inverse & 0.37 & 0.14 & 0.14 & 8.85 \\
Quadratic & 0.40 & 0.16 & 0.16 & 8.73 \\
Cubic & 0.41 & 0.17 & 0.16 & 8.71 \\
\hline
\end{tabular}

$S E$ standard error

$R$ correlation coefficient

$R^{2}$ coefficient of determination

$R^{2}{ }_{\text {adj }}$ adjusted $R^{2}$

$\mathrm{F}(3.311)=152.31, p<0.001 ;$ Platismatia glauca $\mathrm{F}(3.311)=$ $126.913, p<0.001$ (Table 3). The coefficient of determination revealed that subsequent doses of water affected water storage capacity mainly in Hypogymnia tubulosa, to a lesser extent in Platismatia glauca, while in Everenia prunastri the correlation between the two variables was the weakest (Table 4). The dynamics of the process was similar in all analysed taxa. The first doses of water increased water storage capacity dynamically; afterwards it decreased and then slightly increased again. The cubic model for each species is presented in Fig. 7.

\section{Discussion}

The values of water storage capacity in the experiment ranged from $15 \%$ to $33 \%$ and were slightly lower than the results based on mathematical models, calculated for bryophytes and lichens together in the temperate climate zone (Porada et al. 2018). Epiphytes in rainforests, i.e. lichens, bryophytes and ferns, are capable of storing as much as $80 \%$ of rainwater in the initial phase of precipitation (Veneklaas et al. 1990; Fačkovcova et al. 2019). However, our results indicate that, after 21 runs of the experiment, lichen thalli did not achieve the maximum potential water storage capacity. The intensity

Table 2 Parameters of the cubic function relating time and water storage capacity of lichens

\begin{tabular}{lrrrrr}
\hline & \multicolumn{1}{c}{$B$} & \multicolumn{1}{l}{$S E$} & $\beta$ & \multicolumn{1}{l}{$t$} & \multicolumn{1}{c}{$p$} \\
\hline Iteration & 2.90 & 0.53 & 1.85 & 5.51 & $<0.01$ \\
Iteration **2 & -0.18 & 0.05 & -2.61 & -3.30 & $<0.01$ \\
Iteration **3 & 0.00 & 0.00 & 1.13 & 2.33 & 0.02 \\
$(\alpha)$ & 9.86 & 1.37 & & 7.19 & $<0.01$ \\
\hline
\end{tabular}

$t$-value

$p$ probability value

$\beta$ standardised coefficient

$B$ unstandardised coefficient (results in measurement scale)

$S E$ standard error

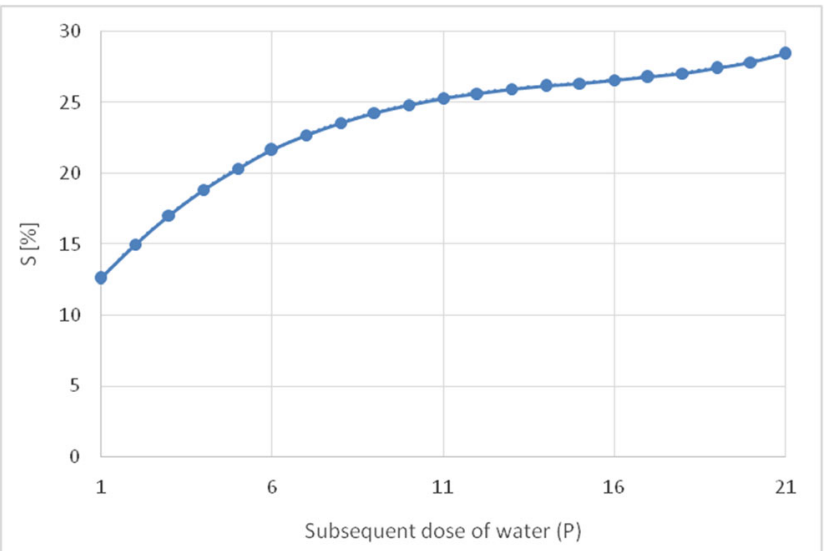

Fig. 6 Cubic function relating time (subsequent doses of water) and water storage capacity of water by all three lichen species

of simulated rainfall was not high, which proves that precipitation of low intensity adversely affects the time required for gaining the maximum water storage capacity (Klamerus-Iwan 2014). Obtaining the results that are lower than in other studies may also result from obtaining the values of water storage capacity that were close to those under field conditions.

The differences in the amount of the water retained could be related to morphological features of the analysed taxa. Platismatia glauca has a foliose, flat thallus with corrugated margins, which increases the capability of rainwater storage. Evernia prunastri with branched, fruticose thallus has an medium water storing capacity. However, the model characterising the relationship between time and changes in the water retained suggests that, in the case of this species, prolonged exposure to rainwater could increase its overall storage capacity. The amounts of stored water were the lowest in Hypogymnia tubulosa with a foliose thallus and convex lobes. The curves of all three cubic models were similar, yet in Platismatia glauca the initial storage capacity was the most dynamic and the curve was the most concave. Additionally, nonvascular epiphytes are able to significantly influence the atmospheric moisture dynamics even during non-rain periods (Pypker et al. 2017).

The anatomical structure of the thallus, including the presence of structures increasing its gas exchange, can be another factor affecting the water storage capacity of lichens (Ahmadjian and Hale 1973). Research on the absorption of contaminants from a water solution suggests that the presence of pores facilitates water absorption. Out of the three analysed species, pseudocyphellae are present in the thalli of Hypogymnia tubulosa and Evernia prunastri, i.e. taxa with lower water storage capacity values, rather than in Platismatia glauca, which does not have such structures. Therefore, the anatomical structure seems to be an important factor, next to the morphology of a thallus and its chemical properties, regulating the amounts of absorbed water. 
Table 3 Relationship between water storage capacity and subsequent doses of simulated rainfall in three analysed lichen species

\begin{tabular}{|c|c|c|c|c|c|c|}
\hline & & $B$ & $S E$ & $\beta$ & $t$ & $p$ \\
\hline \multirow{4}{*}{$\begin{array}{l}\text { Everenia prunastri } \\
\mathrm{F}(3,311)=78,33 ; p<0,001\end{array}$} & Iteration & 2.779 & 0.48 & 2.79 & 5.79 & $<0.01$ \\
\hline & Iteration $* * 2$ & -0.171 & 0.05 & -3.89 & -3.41 & $<0.01$ \\
\hline & Iteration $* * 3$ & 0.004 & 0.00 & 1.70 & 2.43 & 0.02 \\
\hline & (Constant) & 6.878 & 1.25 & & 5.51 & $<0.01$ \\
\hline \multirow{4}{*}{$\begin{array}{l}\text { Hypogymnia tubulosa } \\
\mathrm{F}(3,311)=152,31 ; p<0,001\end{array}$} & Iteration & 2.231 & 0.25 & 3.56 & 8.78 & $<0.01$ \\
\hline & Iteration $* * 2$ & -0.138 & 0.03 & -5.00 & -5.21 & $<0.01$ \\
\hline & Iteration $* * 3$ & 0.003 & 0.00 & 2.12 & 3.60 & $<0.01$ \\
\hline & (Constant) & 5.386 & 0.66 & & 8.15 & $<0.01$ \\
\hline \multirow[t]{4}{*}{ Platismatia glauca $\mathrm{F}(3,311)=126,913 ; p<0,001$} & Iteration & 3.693 & 0.45 & 3.52 & 8.21 & $<0.01$ \\
\hline & Iteration $* * 2$ & -0.235 & 0.05 & -5.07 & -5.01 & $<0.01$ \\
\hline & Iteration $* * 3$ & 0.005 & 0.00 & 2.21 & 3.56 & $<0.01$ \\
\hline & (Constant) & 17.302 & 1.17 & & 14.80 & $<0.01$ \\
\hline
\end{tabular}

$t$-value

$p$ probability value

$\beta$ standardised coefficient

$B$ unstandardised coefficient (results in measurement scale)

$S E$ standard error

Hydrophobicity, characteristic of taxa inhabiting places exposed to rainwater, protects lichens from supersaturation, depressing photosynthesis (Honegger 2007). Additionally, it prevents dissolved pollutants from penetrating the thalli (Hauck et al. 2008). Research on wettability of the thallus surface indicates that Platismatia glauca and Hypogymnia tubulosa are moderately hydrophobic, while Evernia prunastri has a hydrophilic thallus; however, the differences between the analysed taxa were small: the contact angles ranged from $89^{\circ}$ in E. prunastri to $95^{\circ}$ in P. glauca and $96^{\circ}$ in H. tubulosa (Hauck et al. 2008).

Without specialised dermal tissue, lichens are prone to absorb contaminants from the atmospheric air (Tretiach et al. 2007). The use of lichens in biomonitoring leads to delimitation of zones with different air quality (Svoboda 2007; Kubiak 2005), as selected species are more or less vulnerable to air pollution (Kiszka 1990; Bielczyk 2001; Conti and Cecchetti

Table 4 Test results for the analysed models

\begin{tabular}{lllll}
\hline Species & $R$ & $R^{2}$ & $R^{2}$ adj & $S E$ \\
\hline Everenia prunastri & 0.66 & 0.43 & 0.42 & 4.58 \\
Hypogymnia tubulosa & 0.77 & 0.60 & 0.59 & 2.43 \\
Platismatia glauca & 0.74 & 0.55 & 0.55 & 4.29 \\
\hline
\end{tabular}

$S E$ standard error

$R$ correlation coefficient

$R^{2}$ coefficient of determination

$R^{2}$ adj adjusted $R^{2}$
2001). Hypogymnia tubulosa, which in our experiment intercepted the smallest amount of water, is found in areas with moderate air pollution (zone IV) and it is the least sensitive of the three studied species. Everenia prunastri grows under conditions of low pollution (zone V), while Platismatia glauca, the species with the highest interception rate, is the most sensitive one and can be found only in unpolluted areas (zone VI). Therefore, our results concerning water storage capacity indicate future research is merited to assess potential linkages between rainfall interception and absorption of contaminants into thalli. Atmospheric pollution can lead to a decline in species with a higher water storage capacity and, as a consequence, affect the forest water budget. However, in terms of hydrology, nonvascular epiphytes are a major canopy structural factor in the increased rainfall interception observed in old growth forests (Pypker et al. 2005).

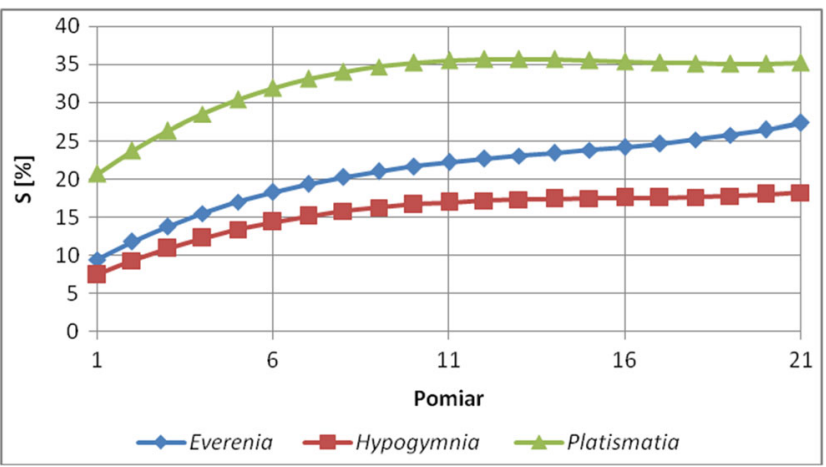

Fig. 7 Cubic functions relating time (subsequent doses of water) and water storage capacity of water by studied lichen species 


\section{Conclusions}

Results on the water storage temporal dynamics and water storage capacity of lichen thalli for three study lichen species differed with regard to morphology and anatomical structure. Water retention was highest in Platismatia glauca, lower in Evernia prunastrii and lowest in Hypogymnia tubulosa. The morphological structure of lichen thalli may be the most important factor explaining differences in water storage temporal dynamics and capacity between analyzed species. The study lichen species with the highest water storage capacity is a species known to be more sensitive to air pollution. Thus, we recommend future research examine (a) how thallus morphology drives rainwater storage capacity and retention, as well as (b) how these rainwater storage and retention dynamics influence thalli's air pollution sensitivity.

Acknowledgments We would like to thank Dr. Anna Łubek (Institute of Biology, Jan Kochanowski University in Kielce) for helping us with identifying lichen species.

\section{Compliance with ethical standards}

Conflict of interest The authors declare no conflict of interest.

Open Access This article is licensed under a Creative Commons Attribution 4.0 International License, which permits use, sharing, adaptation, distribution and reproduction in any medium or format, as long as you give appropriate credit to the original author(s) and the source, provide a link to the Creative Commons licence, and indicate if changes were made. The images or other third party material in this article are included in the article's Creative Commons licence, unless indicated otherwise in a credit line to the material. If material is not included in the article's Creative Commons licence and your intended use is not permitted by statutory regulation or exceeds the permitted use, you will need to obtain permission directly from the copyright holder. To view a copy of this licence, visit http://creativecommons.org/licenses/by/4.0/.

\section{References}

Ahmadjian V, Hale ME (eds) (1973) The Lichens. Academic Press, New York

Bielczyk U (2001) Skala porostowa. W. Szafer Institute of Botany, PASc, Kraków

Bystrek J, Kolanko K (2000) Lichens (Lichenes) of Puszcza Knyszyńska forest. Wydawnictwo Instytutu Biologii Uniwersytetu w Białymstoku, Białystok

Cercasov V, Pantelică A, Sălăgean M, Caniglia G, Scarlat A (2002) Comparative study of the suitability of three lichen species to trace-element air monitoring. Environ Pollut 119:129-139. https:// doi.org/10.1016/S0269-7491(01)00170-1

Cieśliński S (1995) Porosty Puszczy Knyszyńskiej. In: Czerwiński A (ed) Puszcza Knyszyńska. Zespół Parków Krajobrazowych w Supraślu, Supraśl, pp 173-202

Cieśliński S (1997) Porosty. In: Zieliński R (ed) Lasy Puszczy Kozienickiej. Leśny Kompleks Promocyjny, Wydawnictwo SGGW, Warszawa, pp 106-121
Cieśliński S, Tobolewski Z (1988) Lichens (Lichenes) of the Białowieża Forest and its western foreland Phytocoenosis 1 (N. S.). Suppl Cartogr Geobot 1:1-216

Cieśliński S, Czyżewska K, Glanc K (1995) Lichens. In: Faliński JB, Mułenko W (eds) Cryptogamous plants in the forest communities of Białowieża National Park (Project CRYPTO). General problems and taxonomic groups analysis. Phytocoenosis 7 (N.S.) Archivum Geobotanicum 4:75-86

Conti ME, Cecchetti G (2001) Biological monitoring: lichens as bioindicators of air pollution assessment - a review. Environ Pollut 114:471-492. https://doi.org/10.1016/S0269-7491(00) 00224-4

Czarnota P, Kukwa M (2008) Contribution to the knowledge of some poorly known lichens in Poland. II. The genus Psilolechia. Folia Cryptog Estonica 44:9-15. https://pdfs.semanticscholar.org/fb1b/ 39b4ba7470b7c1f7015298775725f811aecc.pdf? ga=2.163892407. 942927516.1579446458-1930090535.1579446458. Accessed Jan 2020

Dohnal M, Černý T, Votrubová J, Tesař M (2014) Rainfall interception and spatial variability of throughfall in spruce stand. J Hydrol Hydromech 62:277-284. https://doi.org/10.2478/johh-2014-0037

Endler Z, Dziedzic J, Koc J (1991) Landscape Park of Borecka Forest complex inventory of plant communities. Acta Academiae Agriculturae ac Technicae Olstenensis, Agricultura 53:3-11

Fačkovcova Z, Guttova A, Benesperi R, Loppi S, Bellini E, Sanita di Toppi L, Paoli L (2019) Retaining unlogged patches in Mediterranean oak forests may preserve threatened forest macrolichens. iForest 12:187-192. https://doi.org/10.3832/ ifor2917-012

Fałtynowicz W (2012) Porosty w lasach - Przewodnik terenowy dla leśników i taksatorów. Centrum Informacyjne Lasów Państwowych, Warszawa. https://www.academia.edu/18498942/ Porosty w lasach. Poradnik terenowy dla le\%C5\%9Bnik\%C3\% B3w_i_taksator\% $3 \%$ B3w-Lichens_in_the forests. Accessed Jan 2020

Figueira C, Menezes de Sequeira M, Vasconcelos R, Prada S (2013) Cloud water interception in the temperate laurel forest of Madeira Island. Hydrol Sci J 58:152-161. https://doi.org/10.1080/02626667. 2012.742952

Garcia-Estringana P, Alonso-Blázquez N, Alegre J (2010) Water storage capacity, stemflow and water funneling in Mediterranean shrubs. J Hydrol 389:363-372. https://doi.org/10.1016/j.jhydrol.2010.06.017

Główny Inspektorat Ochrony Środowiska (2018) Stan środowiska w Polsce. Raport 2018. Biblioteka Monitoringu Środowiska, Warszawa. http://www.gios.gov.pl/images/dokumenty/pms/raporty/ Stan_srodowiska_w_Polsce-Raport_2018.pdf. Accessed Jan 2020

Hauck M, Jürgens SR, Brinkmann M, Herminghaus S (2008) Surface hydrophobicity causes $\mathrm{SO}_{2}$ tolerance in lichens. Ann Bot 101(4): 531-539. https://doi.org/10.1093/aob/mcm306

Hawksworth DL, Rose F (1970) Qualitative scale for estimating sulphur dioxide air pollution in England and Wales using epiphytic lichens. Nature 227:45-148. https://doi.org/10.1038/227145a0

Honegger R (2007) Water relations in lichens. In: Gadd GM, Watkinson SC, Dyer P (eds) Fungi in the environment. Cambridge University Press, Cambridge

Jóźwiak M (2014) The use of indicative organisms in bioindication of land and water environments with chosen examples. Kieleckie Towarzystwo Naukowe, Kielce

Kiszka J (1990) Licheno-indication of the area of the Cracow voivodeship. Studia Ośrodka Dokumentacji Fizjograficznej 18: 201-212

Klamerus-Iwan A (2014) Potential interception in laboratory condition under simulated rain with low intensity. Sylwan 158(4):292-297. https://sylwan.lasy.gov.pl/apex/f?p=sylwan:10:0::NO::P10 NAZWA_PLIKU,P10_ARTYKUL,P10_ZESZYT_NEW: 
F2068422948/2014_04_292au.pdf,2013063,2014_4. Accessed Jan 2020

Kondracki J (1972) Polska północno-wschodnia. Państwowe Wydawnictwo Naukowe, Warszawa

Kubiak D (2005) Lichens and lichenicolous fungi of Olsztyn town (NE Poland). Acta Mycol 40(2):293-332

Lichner L, Holko L, Zhukova N, Schacht K, Rajkai K, Fodor N, Sándor R (2012) Plants and biological soil crust influence the hydrophysical parameters and water flow in an aeolian sandy soil. J Hydrol Hydromech 60:309-318. https://doi.org/10.2478/v10098-0120027-y

Maphangwa KW, Musil CF, Raitt L, Zedda L (2012) Differential interception and evaporation of fog, dew and water vapour and elemental accumulation by lichens explain their relative abundance in a coastal desert. J Arid Environ 82:71-80. https://doi.org/10.1016/j.jaridenv. 2012.02.003

Matuszkiewicz JM (2005) Zespoły leśne Polski. Wydawnictwo Naukowe PWN, Warszawa

Phinney NH (2019) 3D modelling of thallus topography of Lobaria pulmonaria facilitates understanding of water storage pools. Lichenologist 51(1):89-95. https://doi.org/10.1017/ S0024282918000531

Polakowski B (1961) Stosunki florystyczno-fitosocjologiczne Puszczy Boreckiej ze szczególnym uwzględnieniem lasów leśnictwa Lipowo i Walisko. Studia Societatis Scientarum Torunensis D 5:1146

Polakowski B (1963) Die Geobotanische Verhaltnisse im Östlichen Pomorze. Zeszyty Wyższej Szkoły Rolniczej w Olsztynie 15(1):1167

Porada P, Weber B, Elbert W, Pöschl U, Kleidon A (2014) Estimating impacts of lichens and bryophytes on global biogeochemical cycles. Glob Biogeochem Cycles 28:71-85. https://doi.org/10.1002/ 2013GB004705

Porada P, Van Stan IIJT, Kleidon A (2018) Significant contribution of non-vascular vegetation to global rainfall interception. Nat Geosci 11:563-567. https://doi.org/10.1038/s41561-018-0176-7

Prada S, de Sequeira MM, Figueira C, da Silva MA (2009) Fog precipitation and rainfall interception in the natural forests of Madeira Island (Portugal). Agr Forest Meteorol 149:1179-1187. https://doi. org/10.1016/j.agrformet.2009.02.010

Prada S, de Sequeira MM, Figueira C, Vasconcelos R (2012) Cloud water interception in the high altitude tree heath forest (Erica arborea L.) of Paul da Serra Massif (Madeira, Portugal). Hydrol Process 26: 202-212. https://doi.org/10.1002/hyp.8126

Pypker TG, Bond BJ, Link TE, Marks D, Unsworth MH (2005) The importance of canopy structure in controlling the interception loss of rainfall: Examples from a young and an old-growth Dougas-fir forest. Agr Forest Meteorol 130:113-129. https://doi.org/10.1016/j. agrformet.2005.03.003

Pypker TG, Unsworth MH, Bond BJ (2006) The role of epiphytes in rainfall interception by forests in the Pacific Northwest. II. Field measurements at the branch and canopy scale. Can J For Res 36: 819-832. https://doi.org/10.1139/x05-286

Pypker TG, Unsworth MH, Van Stan IIJT, Bond BJ (2017) The absorption and evaporation of water vapor by epiphytes in an old-growth
Douglas-fir forest during the seasonal summer dry season: implications for the canopy energy budget. Ecohydrology 10(3). https://doi. org/10.1002/eco.1801

Skotak K, Degórska A, Prządka Z, Białoskórska U, Typiak-Nowak D, Bratkowski J (2018) Stan i przemiany środowiska przyrodniczego geoekosystemu zlewni jeziora Łękuk. In: Kostrzewski A, Majewski M (eds) Stan i przemiany środowiska przyrodniczego geoekosystemów Polski w latach 1994-2015 w oparciu o realizację programu Zintegrowanego Monitoringu Środowiska Przyrodniczego. Biblioteka Monitoringu Środowiska, Warszawa pp 125-160 http://zmsp.gios.gov.pl/wp-content/uploads/2016/11/ raport 1994-2015.pdf. Accessed Jan 2020

Stopa-Boryczka M (ed) (1986) Atlas współzależności parametrów meteorologicznych i geograficznych w Polsce. IV. Klimat północno-wschodniej Polski. Wydawnictwo Uniwersytetu Warszawskiego, Warszawa

Šurda P, Lichner L, Nagy V, Kollár J, Iovino M, Horel Á (2015) Effects of vegetation at different succession stages on soil properties and water flow in sandy soil. Biologia 70:1474-1479. https://doi.org/10.1515/ biolog-2015-0172

Svoboda D (2007) Evaluation of the European method for mapping lichen diversity (LDV) as an indicator of environmental stress in the Czech Republic. Biologia 62(4):424-431. https://doi.org/10.2478/ s11756-007-0085-5

Tretiach M, Adamo P, Bargagli R, Baruffo L, Carletti L, Crisafulli P, Giordano S, Modenesi P, Orlando S, Pittao E (2007) Lichen and moss bags as monitoring devices in urban areas. Part I: Influence of exposure on sample vitality. Environ Pollut 146:380-391. https:// doi.org/10.1016/j.envpol.2006.03.046

Van Stan IIJT, Pypker TG (2015) A review and evaluation of forest canopy epiphyte roles in the partitioning and chemical enrichment of precipitation. Sci Total Environ 536:813-824. https://doi.org/10. 1016/j.scitotenv.2015.07.134

Veneklaas EJ, Zagt RJ, Van Leerdam A, Van Ek R, Broekhoven AJ, Van Genderen M (1990) Hydrological properties of the epiphyte mass of a montane tropical rain forest, Colombia. Vegetatio 89:183-192. https://doi.org/10.1007/BF00032170

Woś A (1999) Klimat Polski. Wydawnictwo Naukowe PWN, Warszawa

Yousefi S, Sadeghi SH, Mirzaee S, van der Ploeg M, Keesstra S, Cerdà A (2018) Spatio-temporal variation of throughfall in a hyrcanian plain forest stand in Northern Iran. J Hydrol Hydromech 66:97-106. https://doi.org/10.1515/johh-2017-0034

Zalewska A (2012) Ecology of lichens of the Puszcza Borecka Forest (NE Poland). W. Szafer Institute of Botany, PASc, Kraków. https:// www.researchgate.net/publication/301351123_Ecology_of lichens of the Puszcza Borecka_Forest_NE_Poland. Accessed Jan 2020

https://en.tutiempo.net/climate/2019/ws-122800.html. Accessed Jan 2020

Publisher's note Springer Nature remains neutral with regard to jurisdictional claims in published maps and institutional affiliations. 